\title{
BUSINESS MODEL CANVAS AS AN ANALYTICAL TOOL FOR THE EVALUATION OF COMPANIES: CASE STUDY FOR THE AUDIOVISUAL INDUSTRY IN BOGOTA, COLOMBIA
}

\author{
J.A. Ruiz-Ramirez ${ }^{1 *}$, D.F. Reyes-Cancino ${ }^{1 *} \&$ C.J. Arenas-Castro ${ }^{1}$
}

\section{ARTICLE INFO}

\section{Article details}

Submitted by authors $\quad 3$ Jun 2019

Accepted for publication 5 Nov 2019

Available online 12 Dec 2019

\section{Contact details}

Corresponding authors alejandra.ruiz.rz@gmail.com diegof.reyescancino@gmail.com

Author affiliations

1 Vice-Rectory for Research, Manuela Beltran University, Colombia

DOI

http://dx.doi.org/10.7166/30-4-2256

\section{ABSTRACT}

The paper discusses analytical applications of the business model canvas (BMC) formulated by Osterwalder \& Pigneur [1]. From this model, a methodological tool was devised and used as part of an academic research project, in which the categories (blocks) of the BMC were taken as conceptual categories and further processed through a failure mode and effects analysis (FMEA). The specifics of reversing the business model canvas are examined, since the model was conceived for entrepreneurs and not strictly for the analysis of pre-existing companies. The application of the tool was done within the multidisciplinary mixed methods (quantitative and qualitative) project 'Business dynamics of the audiovisual industry in Bogota', which was carried out from October 2017 to May 2019 at Manuela Beltran University in Bogota, Colombia. The methodological tool was applied to 32 key companies and four institutions of the local audiovisual industry through semi-structured interviews with people in managerial positions. The nine blocks of the BMC were conceptually developed to analyse the empirical data, holding them as internal variables. The assessment of the variables revealed opportunities for the growth and development of the companies and the whole industry, as well as patterns for the existing business models of the companies.

\section{OPSOMMING}

Hierdie artikel bespreek analitiese toepassing van die besigheidsmodel skilderdoek soos deur Osterwalder \& Pigneur [1] formuleer. Van hierdie model is ' $n$ metodologiewerktuig uitgedink en gebruik in 'n navorsingsprojek. Die kategorieë (of blokke) van die besigheidsmodel is as konseptuele kategorieë gebruik en verder verwerk tot ' $n$ falingsmode en effekte-analise. Die besonderhede van die aanpassing van die besigheidsmodel skilderdoek is ondersoek, omdat die model aanvanklik vir entrepreneurs eerder as bestaande ondernemings ontwikkel is. Die werktuig is toegepas op 'n multidissiplinêre gemengde-metode projek van die Manuela Beltran Universiteit in Bogota, Colombia. Dié projek is van Oktober 2017 tot Mei 2019 uitgevoer en het die besigheidsdinamika van die oudiovisuele industrie in Bogota ondersoek. Die werktuig is toegepas op 32 sleutel ondernemings en vier institute in die plaaslike oudiovisuele industrie deur vier gedeeltelik gestruktureerde onderhoude met bestuurslede. Die nege blokke van die besigheidsmodel skilderdoek is konseptueel ontwikkel om die empiriese data te ontleed. Hierdie ontleding het groei geleenthede en patrone vir die bestaande besigheidmodelle van die ondernemings ontbloot. 
This paper discusses the empirical implementation of methodological tools related to Osterwalder \& Pigneur's [1] business model canvas (BMC), and its further data processing through a failure mode and effects analysis (FMEA). The empirical research was applied to a regional audiovisual industry -that is, to the companies that are involved in the production, distribution, and/or commercialisation of cinema (films), television programmes, and/or advertising commercials in Bogota, Colombia (South America). Note that we chose to use the term 'audiovisual' as an umbrella term for all these types of creative product.

Following Pardo [2], we believe that to have an accurate academic evaluation of cultural and creative industries $(\mathrm{CCl})$, one must consider a mixed methods and multidisciplinary approach to their underlying aspects - 'a unified point-of-view', bringing insight into the creative and business aspects of the companies and their products. We believe that, to understand fully the cultural or creative products of such business activities, researchers should adopt a serious qualitative approach to complement the habitual quantitative research that is carried out in that area by academics, NGOs, and governmental (local or international) entities.

With our research project, 'Business dynamics of the audiovisual industry in Bogota' [3], we aimed to overcome the limitations of having only quantitative data by using and redesigning existing qualitative methods as well. Our study intended to highlight the economic interrelationships of the audiovisual industry, and its business management side.

Overall, we will provide some insight into the adaptation of the concepts of the business model canvas (BMC) as an analytical tool. The paper is structured as follows: Section 2 has a review of the literature about the methodological tools; Section 3 describes our method and methodological tools; Section 4 shares our main results regarding the tools; and finally, Section 5 serves as a discussion of the implications, the limitations, and the conclusions.

\section{LITERATURE REVIEW ABOUT THE METHODOLOGICAL TOOLS}

\subsection{Considerations regarding the Business Model Canvas}

As mentioned by Keane, Cormican \& Sheahan [4], who reference Blank [5], Massa \& Tucci [6], and Trimi \& Berbegal-Mirabent [7], Osterwalder's [8] business model canvas (BMC) is popular among entrepreneurs because it helps them to make sense of 'doing business'. In this sense, it is a relevant model for a developing industry, especially one with mostly small and medium-sized companies that need to 'make sense of doing business'.

Furthermore, Keane et al. [4] reveal three fundamental aspects that apply to this paper: (a) the dimensionality or the conceptual development of the BMC's nine categories is an issue; (b) entrepreneurs and managers interpret the BMC in different ways; and (c):

“...a search of the entrepreneurship literature revealed only seven studies, none of which have attempted to represent the nine BMC elements by a smaller set." [4]

We also consider Osterwalder [8], Zott, Amit \& Massa [9], and Fielt [10], who all agree that there is no specific and agreed definition of what a 'business model' is. Academic developments on this topic are subject to its treatment by diverse authors. In the light of this, we consider that Osterwalder's $\mathrm{BMC}$ is a very practical proposal, and that it reconciles many matters stressed by him in his Business Model Ontology (2004) about the business model literature.

\subsection{Failure Mode and Effects Analysis' range of application}

There have been different applications of the failure mode and effects analysis (FMEA) tool as a management support tool for many different processes in various fields of work - beyond its implementation in the production of industrial goods.

Price \& Taylor [11] report the application of FMEA in the study of faults in complex simulation systems. Production systems are complemented by industrial engineering tools, such as process diagrams, performance indicators, etc. Paparella [12] and Reiling [13] highlight its use in risk management for hospital services. 
Cantorski \& Garrafa [14] mention that activities in the primary sector need preventive and corrective actions through an FMEA, which would stress corrective measures in an economic sector that has difficulties in detecting process failures. Bertolini [15] references its recent application in different stages of agro-industrial systems.

Finally, Rotondaro [16] considers the implementation of the FMEA in the tertiary or services sector, proposing the incorporation of elements into the classical FMEA so that they address aspects for the provision of services. The adapted tool is named 'service failure mode and effects analysis' (SFMEA).

\section{3}

\section{METHOD}

For our business management analysis, and according to our mixed methods approach, we designed a semi-structured questionnaire that would mostly give us answers of a qualitative nature. However, our goal was to codify the information of these open answers under the nine blocks of the BMC, so that we could eventually transpose it to quantitative terms through the guides and application of an FMEA.

\subsection{The BMC as a methodological tool}

As a result of our literature review, we emphasised on a descriptive and statistical analysis of the participants of this industry, funded by UNESCO and implemented by the Chamber of Commerce of Bogota [17]. For this study's field work, they randomly sampled 1374 companies from the pool of registered companies and held structured interviews about their business practices.

Partnering with them, we took their questionnaire as a basis for creating our own. We developed some of the existing questions and created our own, stressing the qualitative side. Considering that the BMC is based on nine structured categories (blocks), our questions were structured in line with them, so that they would correspond with those main elements of business practice [1].

The questionnaire topics were organised according to the BMC, but were still designed for holding semi-structured interviews. Moreover, the sample was decreased to 36 subjects, with a non-random discretionary sampling, choosing key participants of the local audiovisual industry. This manageable sample allowed us to conduct in-depth interviews with them, amounting to 70 hours of audio.

While numbers and statistics show the overall tendencies of the market, the nuances of everyday decisions, strengths, and problems make it necessary to enquire about the 'whys' and the stories behind certain situations. This information was crucial for evaluating the management side. Processing this qualitative data subsequently led to establishing subcategories, which were then applied and quantified using an FMEA analysis.

\subsubsection{Field work}

The semi-structured interviews with the BMC-based questionnaire were an integral part of our qualitative methodology; however, we complemented the questionnaire with ethnographic methods. Both interviews and ethnographies are recurrent tools in business anthropology [18] and economic anthropology [19]. Additional ethnographical formats were also used.

Ethnographic interviews are defined as a technique to observe an interviewed person and interpret their responses and the data collected during the interview [20]. It is applied in investigations where researchers and interviewees, through their interpretations, try to make visible a complex phenomenon or context (cultural, environmental, or economic) [21].

In that sense, our research applied the ethnographic semi-structured interviews to understand better the business dynamics of the selected 36 participants. The ethnographic interviews expanded the nine BMC categories through enquiring about the sociocultural context and the specifics of the participants' main business activities, with details that were explored more deeply as they arose during the interviews.

Each session took between 30 minutes and two hours, with the average being one hour and 30 minutes. The duration depended on the ease of speech of each participant, their willingness to provide meaningful insights, and their availability. Audio was always recorded for its further written transcription. 
Both business anthropology and economic anthropology were established as a way to understand the tangible and intangible elements related to modern economic activities. On the one hand, business anthropology focuses on organisational changes and the sociocultural context of companies in a globalised world [18]. On the other hand, economic anthropology has a general interest in the social context of the production and distribution of the consumption of goods and services [19].

\subsection{Qualitative data analysis}

In qualitative research, data is coded under predefined categories or under new ones that arise from the actual analysis of the collected data, as mentioned by Hernández-Sampieri, Fernández-Collado \& Baptista-Lucio [22]. According to Coffey \& Atkinson [23], coding consists of identifying important questions in the data, analysing these issues to discover similarities and differences, and retrieving examples that illustrate the issues.

Grounded theory, as formulated by Glaser \& Strauss [24], is one of many strategies in qualitative research, and is quite useful for phenomena or specific problems that are not much discussed in academic literature, as mentioned by Creswell [25]. It provides theoretical explanations from the data obtained during the investigation. This should be contrasted to the hypothetico-deductive method, in which researchers largely depend on accepted theories to generate their own investigations, experiments, and results [22]. Two strengths of grounded theory are its concrete and practical way to analyse data, and its sensitivity towards the expressions of the studied subjects.

There is only a limited academic literature about the emerging audiovisual industry of Colombia or Bogota; hence our choice of a grounded theory approach. Most referenced theoretical literature refers to the main business and economic aspects of consolidated industries, such as the film industries in the USA (Hollywood) or in Europe.

\subsubsection{Data coding}

To be able to codify, all 36 interviews from our field work were transcribed in an intelligent verbatim transcription style, which omits distracting filler or repeated words while maintaining the essence of the speech. These interviews, and the most relevant bibliography, were then uploaded and organised in folders in NVivo 12 software, which allows one to code and analyse information.

We subsequently established nodes, which in this software means specific topics or themes in the investigation. We created nodes to reflect conceptual categories and subcategories according to our theoretical referents and our analytical sweeps of the data.

The first analytical sweep (or 'open coding') yielded more than 400 codes, which was a first approximation to the issues of each category. Likewise, memos and annotations were written as communication between the researchers about new categories or gaps in the analysis.

Our six main conceptual categories were: (1) Business Model Canvas; (2) anecdotes; (3) institutions; (4) competition; (5) audiovisual industry context; and (6) organisational structure.

Category 1 is the nine BMC categories. For each of these nine blocks, and for categories 2 and 3 , we created subcategories that were used for codification of the transcripts (see section 4.1).

Thus, for each BMC category we created thematic subcategories that we grounded on the empirical data, or that were based on the business academic literature. We believe that these subcategories brought dimensionality to the otherwise broad BMC conceptual categories - a weakness alluded to by Keane et al. [4].

When coding an interview, we read a transcript and selected the extracts that best represented the views within the categories and subcategories. That gave us units of analysis in a twofold way. On the one hand, the empirical information gathered from the managers and entrepreneurs on behalf of their companies was crucial in providing details about the BMC and the other categories. On the other hand, we could evaluate the 'occurrence' of statements within each category, the level of 'detection' of their issues and decide on their 'severity'. This was crucial for the application of the FMEA.

\subsubsection{Data validation}

Once the first sweep (or open coding) was done, the results were passed on to the rest of the research group (seven investigators in total) who validated both the categories and the coding of 
the transcripts. The validation process is intended to verify whether the units of analysis are positively related to the meanings of each code. It also assesses whether the codes are robust enough to explain the topics and keep them in the analysis, and it reviews any emerging categories [22].

Each researcher, using their expertise, reviewed the categories, subcategories and codified text of the transcripts. This analytical exercise ends once there are no more categories to explore, at which point a 'saturation of categories' occurs [22].

\subsection{The FMEA tool for applying qualitative data}

\subsubsection{FMEA generalities}

Teng \& Ho [26] mention that an FMEA is a known systematic and structured way to detect system failure modes and evaluate the effects and consequences of failure modes. According to Ahmed [27], FMEA also offers an approach to ensure product reliability and is, therefore, strongly connected to product usage conditions and environments.

There are two main types of FMEA, as mentioned by Banduka [28]: (a) the analysis related to the design phase, shortened to DFMEA; and (b) the analysis related to productive processes, shortened to PFMEA. A crucial difference is that, for the DFMEA, the end user is a distant entity, whereas for the PFMEA, the end user could be the next user in the process.

For a good application of an FMEA, Gorny [29] suggests that, in its first stage of analysis, a supervising team should be appointed for a product, process or design. This team must then identify all the occurrences and areas where possible errors and problems might arise, in order to determine the measures to eliminate these errors.

The following stages of the FMEA process should include: (a) identifying all the elements of a product; (b) identifying all the stages in the process; (c) pointing out possible errors; (d) indicating the possible results of those errors; and (e) asserting the causes of those possible errors. In addition to this, the risk priority number (RPN) must be calculated, based on: severity (S), occurrence (O), and detection (D).

$$
R P N=[S] *[O] *[D]
$$

\subsubsection{Adaptation of the FMEA}

Following Tarantino \& Cernauskas [30], who describe the FMEA as a tool of six sigma programmes, we proceeded to identify failure modes in our subject industry, as well as the causes and effects of these failures. Expert knowledge is fundamental to prioritising which elements affect process performance -in this case, adapted for the performance of the industry in business model terms.

An FMEA worksheet was therefore adapted so that it would include the BMC categories and the subcategories (see section 3.2) as variables, and failure modes were associated with each one of them. Moreover, a scale was also produced to be able to rate the severity, occurrence, and detection values, so that the RPN could be calculated, based on the BMC codified data.

Table 1: Scale for severity, occurrence and detection

\begin{tabular}{|c|c|}
\hline \multicolumn{2}{|c|}{ SEVERITY } \\
\hline Very high & 5 \\
\hline High & 4 \\
\hline Moderate & 3 \\
\hline Low & 2 \\
\hline Remote & 1 \\
\hline
\end{tabular}

\begin{tabular}{|c|c|}
\hline \multicolumn{2}{|c|}{ OCCURRENCE } \\
\hline Very high & 5 \\
\hline High & 4 \\
\hline Moderate & 3 \\
\hline Low & 2 \\
\hline Remote & 1 \\
\hline
\end{tabular}

\begin{tabular}{|c|c|}
\hline \multicolumn{2}{|c|}{ DETECTION } \\
\hline Very high & 1 \\
\hline High & 2 \\
\hline Moderate & 3 \\
\hline Low & 4 \\
\hline Remote & 5 \\
\hline
\end{tabular}


Table 2: Adapted FMEA worksheet

\begin{tabular}{|c|c|c|c|c|c|c|c|c|c|c|c|c|c|c|}
\hline \multirow{2}{*}{ 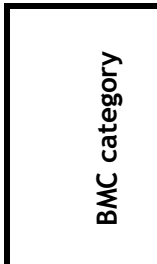 } & \multirow[b]{2}{*}{ 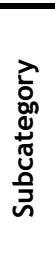 } & \multirow[b]{2}{*}{ 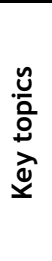 } & \multirow{2}{*}{ 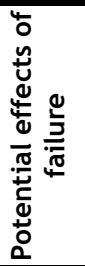 } & \multirow[b]{2}{*}{ 췬 } & \multirow[b]{2}{*}{ 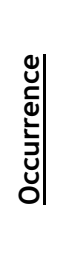 } & \multirow[b]{2}{*}{ 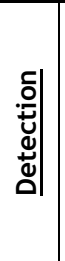 } & \multirow[b]{2}{*}{$\underset{z}{\alpha}$} & \multirow[b]{2}{*}{ 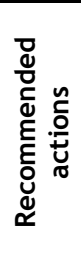 } & \multirow{2}{*}{ 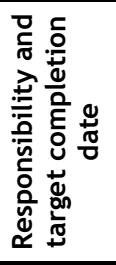 } & \multicolumn{5}{|c|}{ Action results } \\
\hline & & & & & & & & & & 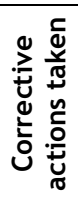 & 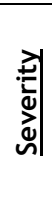 & 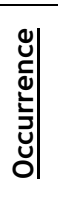 & 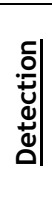 & $\frac{z}{\alpha}$ \\
\hline $\begin{array}{l}\text { A. Custom } \\
\text { segments }\end{array}$ & & & & & & & & & & & & & & \\
\hline $\begin{array}{l}\text { B. Value } \\
\text { propositio }\end{array}$ & & & & & & & & & & & & & & \\
\hline C. Channe & & & & & & & & & & & & & & \\
\hline $\begin{array}{l}\text { D. Custom } \\
\text { relationsh }\end{array}$ & & & & & & & & & & & & & & \\
\hline $\begin{array}{l}\text { E. Revenu } \\
\text { streams }\end{array}$ & & & & & & & & & & & & & & \\
\hline $\begin{array}{l}F . \text { Key } \\
\text { resources }\end{array}$ & & & & & & & & & & & & & & \\
\hline $\begin{array}{l}\text { G. Key } \\
\text { activities }\end{array}$ & & & & & & & & & & & & & & \\
\hline $\begin{array}{l}\text { H. Key } \\
\text { partners }\end{array}$ & & & & & & & & & & & & & & \\
\hline $\begin{array}{l}\text { I. Cost } \\
\text { structure }\end{array}$ & & & & & & & & & & & & & & \\
\hline
\end{tabular}

\section{$4 \quad$ RESULTS}

Since this paper focuses on the methodological tools, we will highlight the results that directly influenced these tools, and only partially highlight the results we obtained from the analysis of the audiovisual industry in Bogota (to illustrate the use of the tools).

\subsection{BMC qualitative categorising}

Once the 'open coding' phase finished with the empirical data, we carried out the validation process. This meant a thorough revision of the coded text of the transcripts, which yielded recommendations from the researchers about the initial codes. From the original proposed ones, we finally agreed on 59 subcategories.

Of these, 33 subcategories were related to the nine categories (blocks) of the BMC, as follows:

All these codes represented opinions or issues expressed by our 36 subjects. They were analysed in qualitative terms, to show the researchers a general pattern in certain issues, or to highlight crucial elements even when expressed by only one or a few persons.

These exceptional circumstances are sometimes overlooked by quantitative research, as they are abnormal and/or infrequent; however, the FMEA can distinguish between 'occurrence' and 'severity'. This is the main contribution of quantifying after having done the qualitative analysis.

For the sake of illustrating our methodological tool, we present some of the qualitative results for the BMC's 'customer segments' for the audiovisual industry in Bogota [3]. 
Table 3: Codes for the empirical data per category

\begin{tabular}{|c|c|c|c|}
\hline \multicolumn{2}{|c|}{ CATEGORIES } & SUBCATEGORIES & $\begin{array}{l}\text { NUMBER OF } \\
\text { CODES }\end{array}$ \\
\hline \multirow{33}{*}{ 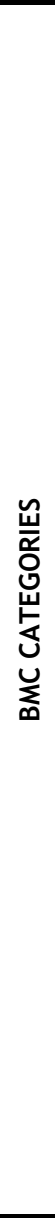 } & \multirow{3}{*}{ A. Customer segments } & Diversified market & \multirow{3}{*}{32} \\
\hline & & Multi-sided market & \\
\hline & & Niche market & \\
\hline & \multirow{4}{*}{ B. Value propositions } & Quality & \multirow{4}{*}{32} \\
\hline & & Brand - Status & \\
\hline & & Differentiation versus competition & \\
\hline & & Customer comfort & \\
\hline & \multirow{3}{*}{ C. Channels } & Indirect channel & \multirow{3}{*}{13} \\
\hline & & Direct channel & \\
\hline & & Advertising of the products & \\
\hline & \multirow{3}{*}{$\begin{array}{l}\text { D. Customer } \\
\text { relationships }\end{array}$} & Internal \& external customer & \multirow{3}{*}{19} \\
\hline & & Customer loyalty & \\
\hline & & Feedback & \\
\hline & \multirow{6}{*}{$E$. Revenue streams } & $\begin{array}{l}\text { Financing } \\
\end{array}$ & \multirow{6}{*}{108} \\
\hline & & Most profitable (product or service) & \\
\hline & & Cash flow + Advance payments & \\
\hline & & Investments & \\
\hline & & Sales & \\
\hline & & Sales of exploitation rights & \\
\hline & \multirow{7}{*}{$F$. Key resources } & Administrative & \multirow{7}{*}{71} \\
\hline & & Financial & \\
\hline & & Physical - Infrastructure & \\
\hline & & Intellectual & \\
\hline & & Human & \\
\hline & & Financial positions & \\
\hline & & Training & \\
\hline & \multirow{4}{*}{ G. Key activities } & Prices (strategies) \& Quotations & \multirow{4}{*}{68} \\
\hline & & Creating the product or service & \\
\hline & & Specialised \& Standardised processes & \\
\hline & & Pre- \& post-sale & \\
\hline & H. Key partners & $\begin{array}{l}\text { Alliances for the consolidation of the audiovisual } \\
\text { industry }\end{array}$ & \multirow[t]{2}{*}{27} \\
\hline & & Outsourcing & \\
\hline & I. Cost structure & Fixed costs \& variable costs & 11 \\
\hline \multirow{9}{*}{\multicolumn{2}{|c|}{ Anecdotes }} & Creation of the company & \multirow{9}{*}{142} \\
\hline & & Choice of projects & \\
\hline & & Ethics \& professional ethics & \\
\hline & & Formalisation vs Informality & \\
\hline & & Internationalisation of markets & \\
\hline & & Personal involvement & \\
\hline & & Projects & \\
\hline & & Bankruptcy & \\
\hline & & Creative or financial risks & \\
\hline \multirow{5}{*}{\multicolumn{2}{|c|}{ Institutions }} & Policy implementation & \multirow{5}{*}{56} \\
\hline & & Policy gaps & \\
\hline & & Institutions \& sector policies & \\
\hline & & Regulations (laws) & \\
\hline & & Initiatives & \\
\hline & Competition & $N / A$ & 10 \\
\hline & visual industry context & $N / A$ & 47 \\
\hline & sanisational structure & $N / A$ & 31 \\
\hline & & & $\frac{667}{\text { total codes }}$ \\
\hline
\end{tabular}

\subsubsection{BMC's customer segments}

This BMC category evaluates the way in which the companies relate to their customers, and the way they might be grouped into segments, in order to better satisfy their needs [1]. 
As mentioned in Table 3, we established three subcategories and 32 codes (our subjects' views) for this BMC category. For each subcategory, we identified key topics as they arose and started to elaborate patterns.

The information was organised for all categories as seen in the abridged sample in Table 4. For the sake of clarity, we have mildly adapted the translated speech of the interviewed subjects and included edited responses for five codes (out of the 32 ). Code T stands for an institution; code E for a company.

Table 4: Abridged qualitative analysis of the customer segments

\begin{tabular}{|c|c|c|}
\hline Subcategory & Key topics & $\begin{array}{l}\text { Issues and opinions } \\
\end{array}$ \\
\hline $\begin{array}{l}\text { Diversified } \\
\text { market }\end{array}$ & $\begin{array}{l}\text { Product } \\
\text { variability }\end{array}$ & $\begin{array}{l}\text { "We are in an industry that is engaged in many [different] things. So, one } \\
\text { same company can be making video games, can be doing animation and } \\
\text { it can be making short films." T01 }\end{array}$ \\
\hline $\begin{array}{c}\text { Multi-sided } \\
\text { market }\end{array}$ & $\begin{array}{l}\text { Various } \\
\text { market } \\
\text { platforms }\end{array}$ & $\begin{array}{l}\text { "For now, only cinema; we have not focused on other windows nor other } \\
\text { platforms because we usually only acquire the rights to cinema since we } \\
\text { say that it is the business in which we act, and it is the business that we } \\
\text { know." E23 }\end{array}$ \\
\hline Niche market & Specific niche & $\begin{array}{l}\text { "We really have to highlight that it's a wonder and a miracle that big TV } \\
\text { channels want to make documentaries." E21 } \\
\text { "We have been focusing on an auteur cinema, but reachable, with } \\
\text { communicating vessels with the public; that is, not a hermetic auteur } \\
\text { cinema, but one that can find an audience and transcend borders; films } \\
\text { that enquire about themselves and humanity; not strictly niche cinema." } \\
\text { E06 }\end{array}$ \\
\hline & $\begin{array}{l}\text { New products } \\
\text { in the same } \\
\text { market }\end{array}$ & $\begin{array}{l}\text { "Avant-garde cinema has never been popular. There are no blockbuster } \\
\text { avant-garde films; avant-garde generates losses. But all their discoveries } \\
\text { always have been capitalised by the great entertainment industry.” E12 }\end{array}$ \\
\hline
\end{tabular}

It is worth pointing out that we have opinions from diverse companies for each category, following views like Vause [31], who states, as a rule of corporate analysis, never to judge a company in isolation, but instead, to compare it with related companies.

The qualitative results, when aggregated, reveal a glimpse of the whole market dynamic regarding the segmentation of customers, and not only the performance of simply any given company.

\subsubsection{Qualitative analysis of the BMC's customer segments}

Having codified, verified, and systematised all the empirical data, the researchers took those patterns and outlined 'substantive grounded theories' [24]. The range of these substantive theories encompasses the audiovisual industry in Bogota.

For example, from the codified data in Table 4 above, we concluded that the companies indeed do market segmentation; that many companies have diversified; and that they are reluctant to create niche products, even if they in fact do create them and are depend on them niche relationships between producers and their customers (the audience) have proven to generate value for the companies, as they take advantage of their business strengths and become competitive in a difficult market.

\subsection{FMEA data tabulation}

Once the qualitative data analysis was complete, we proceeded with the implementation of the FMEA. The purpose behind this was to be able to quantify the qualitative results we had acquired. The FMEA takes the categories and subcategories, with special emphasis on the BMC categories, and sets them as a linear combination of variables.

Table 5 below continues the analysis of the 'customer segments' BMC category. The table is a descriptive analysis that develops the subcategories as variables, for the subsequent RPN calculation for each. 
Table 5: Adapted FMEA for the case study of BMC's customer segments

\begin{tabular}{|c|c|c|c|c|c|c|c|c|}
\hline 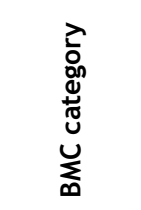 & 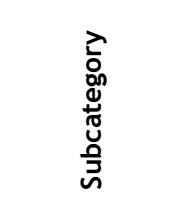 & 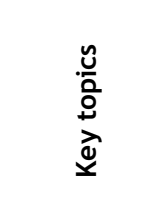 & 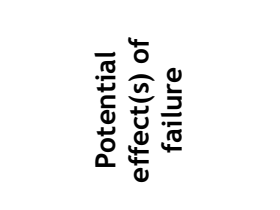 & 勇 & 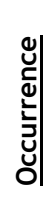 & वీ. & $\frac{z}{\alpha}$ & 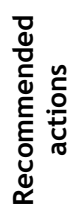 \\
\hline \multirow{3}{*}{$\begin{array}{l}\text { Customer } \\
\text { segments }\end{array}$} & $\begin{array}{l}\text { Diversified } \\
\text { market }\end{array}$ & $\begin{array}{l}\text { Product } \\
\text { variability }\end{array}$ & $\begin{array}{c}\text { Companies } \\
\text { dependent on only } \\
\text { one type of } \\
\text { audiovisual product, } \\
\text { with its variability in } \\
\text { the markets } \\
\text { (financing; demand). }\end{array}$ & 5 & 1 & 1 & 5 & - \\
\hline & $\begin{array}{l}\text { Multi-sided } \\
\text { market }\end{array}$ & $\begin{array}{l}\text { Exploring } \\
\text { various } \\
\text { market } \\
\text { platforms }\end{array}$ & $\begin{array}{l}\text { Under-exploitation of } \\
\text { products that have } \\
\text { the potential to be } \\
\text { commercialised in } \\
\text { secondary markets, } \\
\text { resulting in less } \\
\text { revenue per } \\
\text { investment. }\end{array}$ & 5 & 4 & 1 & 20 & - \\
\hline & Niche market & $\begin{array}{l}\text { Specifying } \\
\text { products for } \\
\text { key } \\
\text { segments }\end{array}$ & $\begin{array}{c}\text { Products lack a } \\
\text { target audience and } \\
\text { are falsely thought to } \\
\text { be 'for all } \\
\text { audiences', to try to } \\
\text { amplify the scope of } \\
\text { demand. }\end{array}$ & 5 & 4 & 1 & 20 & - \\
\hline
\end{tabular}

To calculate the RPN values, the key topics in each of the categories and subcategories were evaluated by our multidisciplinary team of researchers. Since the issues were derived from the interviewed subjects (who expressed the importance of these categories on behalf of their companies), it was agreed that they should all be classified as 'very high severity' (5) for the FMEA. Next, the occurrence and detection values were chosen by the researchers, according to the analysis and interpretation from the empirical data, according to Table 1.

The RPN values reflect the 'development' of each analysed category. The categories with very high RPN values (125 being the maximum possible score) would have to be prioritised, since they have a high risk factor and were identified as 'critical'. On the other hand, categories with lower RPN values show the strengths and good practices of the companies in this sector. This scale is shown in Table 6. It is important conceptually not to confuse RPN values with 'severity'.

Table 6: Development degree per RPN range

\begin{tabular}{|c|c|}
\hline Development degree & RPN range \\
\hline High & $0-20$ \\
\hline Good & $21-50$ \\
\hline Average & $51-70$ \\
\hline Low & $71-100$ \\
\hline Critical & $101-125$ \\
\hline
\end{tabular}

Moreover, one can illustrate through graphs the incidence of the levels of 'development' for each of the BMC subcategories; that is, for each BMC category, how many subcategories fall under each level of development? This can be seen in Figures 1,2, and 3, in different types of graphs. These figures highlight the extent to which one can provide elements of analysis from the quantification of the qualitative data. 


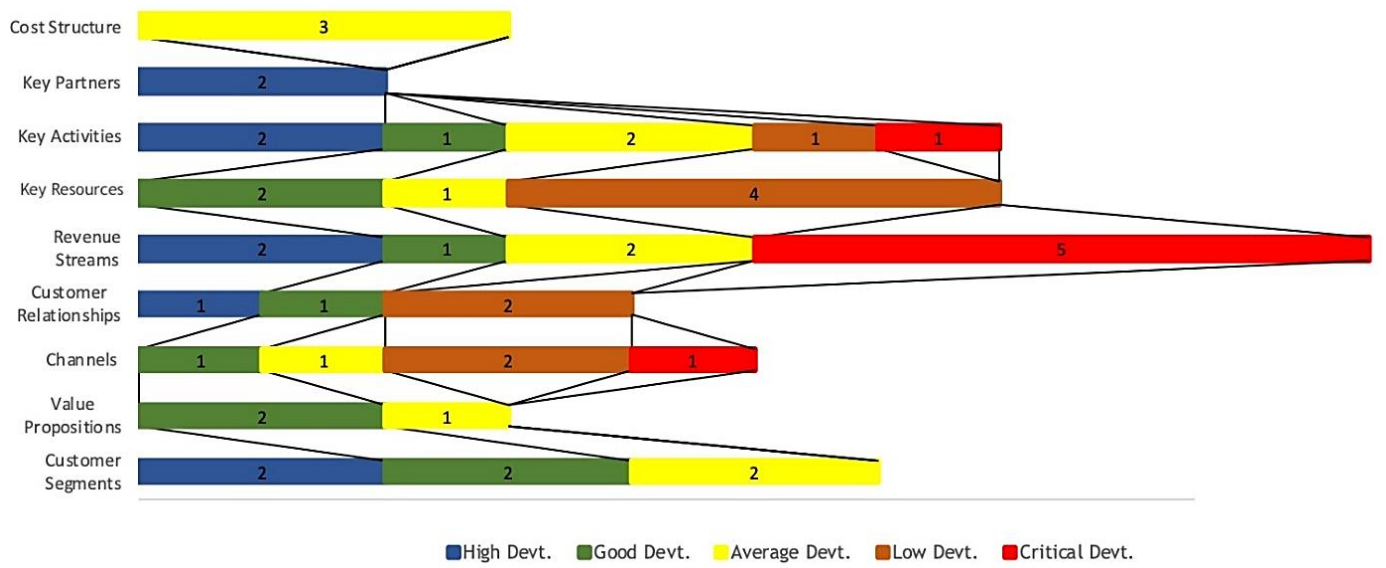

Figure 1: Incidence of development degrees in the BMC subcategories (see online version for colour)

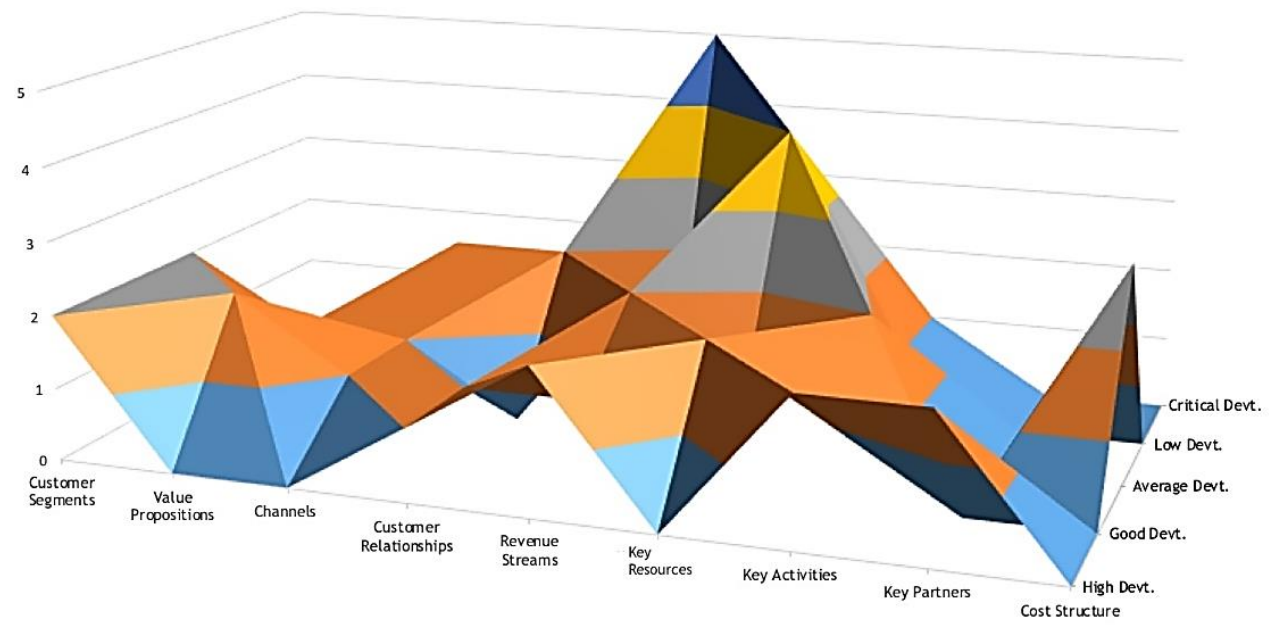

Figure 2: Dimensionality of incidence of development degrees in the BMC subcategories (see online version for colour)

RPN value analyses indicate key factors and improvement opportunities for the nine BMC categories, according to the business model of each of the companies. Likewise, from each BMC category, it was possible to establish each company's activities according to their mission and vision statements, in a way that allowed corporate development and the implementation of actions for the stable operation of the companies within the dynamics of this market.

Researchers were also able to identify market behaviour traits, based on the business dynamics of this industry - especially considering that the companies belonged to different stages of the value system or industry value chain, as stated by Porter [32] - that is, the production, distribution, and commercialisation of audiovisual products. This is of the utmost importance when considering that certain types of companies do not work directly for an end user (the audience), but rather for other companies within this value system, as discussed by Bloore [33] and Pardo [2], [34].

Based on all this, we could provide an in-depth business management view of the economic assessment of the audiovisual industry in Bogota over the studied period (2018). Through the qualitative and quantitative analysis of the BMC, we could understand how companies generate actions to 'survive' and to be involved with other participants in the value system, allowing us to establish trends and challenges for the future. 


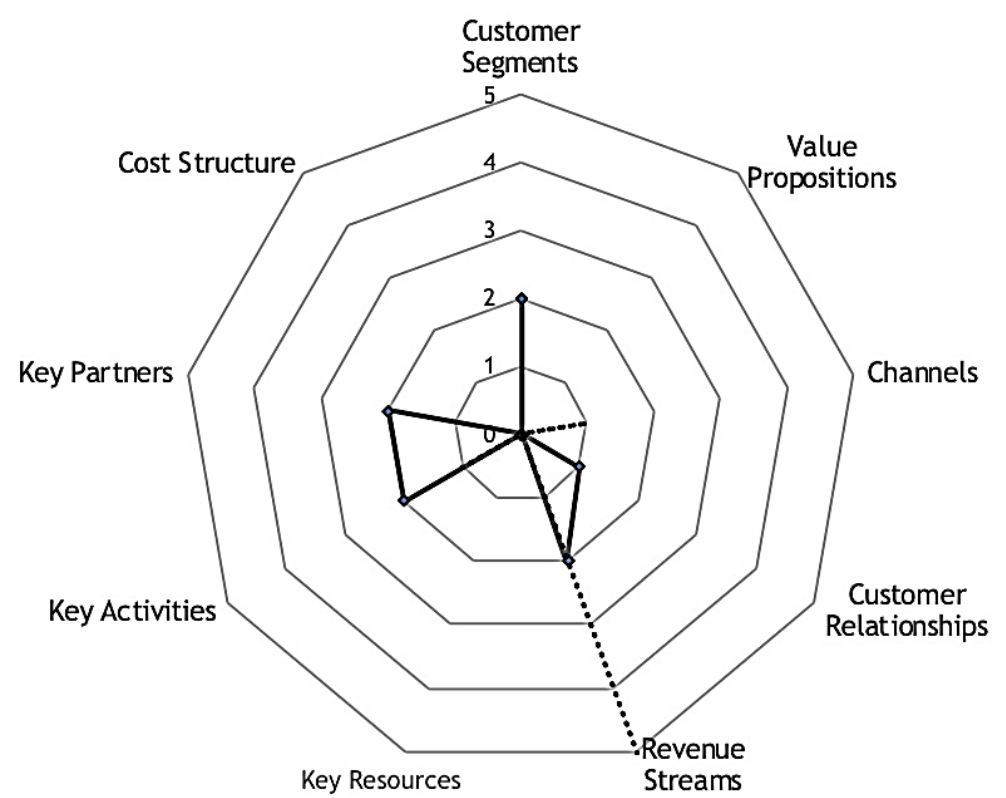

Figure 3: Radar comparison of high and critical developments

To fulfil the research objectives of the project, 'Business dynamics of the audiovisual industry in Bogota' [3], we managed to adapt the BMC categories into an analytical tool for ethnographic interviews and their subsequent analysis.

We applied the ground theory methodology for the qualitative analysis, which yielded information that was then input for a mixed methods approach. For the latter, we merged the BMC and FMEA tools, managing to get the best of both qualitative and quantitative methods using the same empirical data.

\subsection{Implications}

Based on the results, we believe that our use of the methodological tools brought specific benefits for our research purposes, as well as certain challenges.

For the qualitative analysis, we managed to bring a conceptual dimension to the nine BMC categories, creating new complementary categories and generating subcategories that would guide the coding of the empirical data.

For the quantitative analysis, we managed to overcome the limitations of the statistics by applying guided numerical values through the FMEA guides, based on the discretionary academic knowledge of the researchers. Figures and graphs give a further analytical dimension to the issues, faced by the companies, within the BMC categories.

Moreover, for the application of the FMEA worksheet, we believe that the academics can only work up to the 'recommended actions' column, since the academics and researchers can only give considerations grounded on the literature and research data, but it is up to the companies or sectoral policy makers to bring about actions.

Therefore, the columns 'responsibility and target completion date' and the 'action results' (with its own follow-up RPN) transcend the academic analytical exercise. Nevertheless, the last columns could be used by the companies and policy makers if the 'recommended actions' were to be put into place. 
These results imply that our application of the BMC and FMEA tools is a plausible way to engage in a mixed methods research for business management.

\subsection{Limitations}

The audiovisual industry in Bogota, Colombia has generated only a limited academic literature, and is not as developed as the film and TV industries in other countries. Most companies are small or medium-sized, although for our study we also considered large companies.

We chose the BMC for being specially well-liked by entrepreneurs; however, for large established companies, certain questions and concepts were deemed too obvious, as their challenges were not of an organisational or business management nature, but rather about sustaining their 'mature' operations in difficult market dynamics.

Also, regarding the scale in Table 6, one could re-evaluate the RNP ranges and their corresponding degree of development. The breadth of the range for all levels could be the subject of further discussion.

\subsection{Conclusions}

With complex objects of study, sometimes new scientific tools are required to be developed from traditional methodologies. In the case of the audiovisual industry in Bogota, we needed to find creative ways to represent the situation of the companies and the market.

Our use of the BMC and FMEA tools must be further refined and validated through application to other research projects with similar objectives, or could even inspire new adaptations for empirical data collection or data analysis.

We think that our application of the BMC categories within the tools could be useful for business management research in other cultural and creative industries, since there is a plethora of start-up companies that would benefit from this type of business model analysis. Alternatively, one could also consider the application of these tools for developed industries with large and well-established companies, such as the oil and carbon industry in Colombia.

The authors acknowledge that the actual results of the study have to be reported in another paper, since here we only focused on the methodological tools. The results regarding the companies and the 'contents' of the BMC applied to this industry were mostly, sadly, omitted.

\section{REFERENCES}

[1] Osterwalder, A. \& Pigneur, Y. 2010. Business model generation. Hoboken, NJ: John Wiley \& Sons .

[2] Pardo, A. 2015. Fundamentos de producción y gestión de proyectos audiovisuales. Pamplona: Ediciones Universidad de Navarra - EUNSA.

[3] Reyes-Cancino, D.F., Ruiz, J.A., Ávila, J.E., Hernández, R.A., López, N., Saavedra, M.G. \& Torres, P. 2019. Dinamicas empresariales de la industria audiovisual en Bogotá. Bogotá: Universidad Manuela Beltrán. Unpublished final research report.

[4] Keane, S.F., Cormican, K.T. \& Sheahan, J.N. 2018. Comparing how entrepreneurs and managers represent the elements of the business model canvas. Journal of Business Venturing Insights, 9, pp. 65-74.

[5] Blank, S. 2013. Why the lean start-up changes everything. Harvard Business Review, 91(5), pp. 63-72.

[6] Massa, L. \& Tucci, C.L. 2014. Business model innovation. In Dodgson M., Gann, D. \& Phillips N. (Eds.), The Oxford Handbook of Innovation Management (pp. 420-441). Oxford: Oxford University Press.

[7] Trimi, S. \& Berbegal-Mirabent, J. 2012. Business model innovation in entrepreneurship. International Entrepreneurship and Management Journal, 8(4), pp. 449-465.

[8] Osterwalder, A. 2004. The business model ontology: A proposition in a design science approach. Lausanne: Université de Lausanne, Faculté des hautes études commerciales. PhD thesis.

[9] Zott, C., Amit, R. \& Massa, L. 2011. The business model: Recent developments and future research. Journal of Management, 37(4), pp. 1019-1042.

[10] Fielt, E. 2013. Conceptualising business models: Definitions, frameworks and classifications. Journal of Business Models, 1(1), pp. 85-105.

[11] Price, C.J. \& Taylor, N.S. 2002. Automated multiple failure FMEA. Reliability Engineering and System Safety, 76(1), pp. 1-10.

[12] Paparella, S. 2007. Failure mode and effects analysis: A useful tool for risk identification and injury prevention. Journal of Emergency Nursing, 33(4), pp. 367-371.

[13] Reiling, J.G., Knutzen B.L. \& Stoecklein, M. 2003. FMEA: The cure for medical errors. Quality Progress, 36(8), pp. 67-71. 
[14] Cantorski da Rosa, L. \& Garrafa, M. 2009. Análise dos modos de falha e efeitos na otimização dos fatores de produção no cultivo agrícola: Subprocesso colheita da canola. Gestão \& Produção, 16(1), pp.63-73.

[15] Bertolini, M., Bevilacqua, M. \& Massini, R. 2006. FMECA approach to product traceability in the food industry. Food Control, 17(2), pp. 137-145.

[16] Gilioli Rotondaro, R. 2002. SFMEA: Análise do efeito e modo da falha em serviços: Aplicando técnicas de prevenção na melhoria de serviços. Production, 12(2), pp. 54-62.

[17] Cámara de Comercio de Bogotá. 2019. Caracterización industrias culturales y creativas de Bogotá. Bogotá: CCB .

[18] Jordan, A. 2012. The anthropological approach. Business Anthropology, 1(2), pp. 1-8.

[19] Hann, C. \& Hart, K. 2011. Economic Anthropology. Cambridge: Polity Press.

[20] Holstein A. \& Gubrium, F. 1995. The Active Interview. Thousand Oaks, CA: Sage Publications .

[21] Fortun, K. 2012. Ethnography in late industrialism. Cultural Anthropology, 27(3), pp. 446-464.

[22] Hernández Sampieri, R., Fernández Collado, C. \& Baptista Lucio, P. 2010. Metodología de la investigación, 5th edition. México D.F.: McGraw-Hill .

[23] Coffey, A. \& Atkinson, P. 1996. Making sense of qualitative data: Complementary research strategies. Thousand Oaks, CA: Sage Publications .

[24] Glaser, B. \& Strauss, A. 1967. The discovery of grounded theory: Strategies for qualitative research. New Brunswick, NJ: Aldine Transactions .

[25] Creswell, J.W. 2009. Research design: Qualitative, quantitative, and mixed methods approaches, 3rd Edition. Thousand Oaks, CA: Sage Publications .

[26] Ten, S.H. \& Ho, S.Y. 1996. Failure mode and effects analysis: An integrated approach for product design and process control. International Journal of Quality and Reliability Management, 13(5), pp. 8-26.

[27] Ahmed, J. 1996. Modern approaches to product reliability improvement. International Journal of Quality and Reliability Management, 13(3), pp. 27-41.

[28] Banduka, N., Veža, I. \& Bilić, B. 2016. An integrated lean approach to process failure mode and effect analysis (PFMEA): A case study from automotive industry. Advances in Production Engineering \& Management, 11(4), pp. 355-365.

[29] Gorny, A., Dudek-Burlokowska, M. \& Rosza, M. 2013. Application of FMEA method in enterprise focused on quality. Journal of Achievements in Materials and Manufacturing Engineering, 45(1), pp. 89-102.

[30] Tarantino, A. \& Cernauskas, D. 2012. Risk management in finance: Six Sigma and other next-generation techniques. Hoboken, NJ: John Wiley and Sons.

[31] Vause, B. 2015. Guide to analysing companies. London: Profile Books .

[32] Porter, M. 1985. Competitive advantage: Creating and sustaining superior performance. New York, NY: Free Press .

[33] Bloore, P. 2009. Re-defining the independent film value chain. BFI [online]. Retrieved on June 3rd 2019 from https://www.bfi.org.uk/sites/bfi.org.uk/files/downloads/redefining-the-independent-film-valuechain.pdf

[34] Pardo, A. 2016. Producción ejecutiva de proyectos cinematográficos. Pamplona: Ediciones Universidad de Navarra - EUNSA. 